\title{
Biotechnological Applications of Microbial (Per)chlorate Reduction
}

\author{
Ouwei Wang ${ }^{1,2}$ and John D. Coates $1,2,3, *$ \\ 1 Department of Plant and Microbial Biology, University of California, Berkeley, CA 94720, USA; \\ wangouwei@berkeley.edu \\ 2 Energy Biosciences Institute, University of California, Berkeley, CA 94704, USA \\ 3 Environmental Genomics and Systems Biology Division, Lawrence Berkeley National Laboratory, \\ Berkeley, CA 94720, USA \\ * Correspondence: jdcoates@berkeley.edu
}

Received: 5 October 2017; Accepted: 22 November 2017; Published: 24 November 2017

\begin{abstract}
While the microbial degradation of a chloroxyanion-based herbicide was first observed nearly ninety years ago, only recently have researchers elucidated the underlying mechanisms of perchlorate and chlorate [collectively, (per)chlorate] respiration. Although the obvious application of these metabolisms lies in the bioremediation and attenuation of (per)chlorate in contaminated environments, a diversity of alternative and innovative biotechnological applications has been proposed based on the unique metabolic abilities of dissimilatory (per)chlorate-reducing bacteria (DPRB). This is fueled in part by the unique ability of these organisms to generate molecular oxygen as a transient intermediate of the central pathway of (per)chlorate respiration. This ability, along with other novel aspects of the metabolism, have resulted in a wide and disparate range of potential biotechnological applications being proposed, including enzymatic perchlorate detection; gas gangrene therapy; enhanced xenobiotic bioremediation; oil reservoir bio-souring control; chemostat hygiene control; aeration enhancement in industrial bioreactors; and, biogenic oxygen production for planetary exploration. While previous reviews focus on the fundamental science of microbial (per)chlorate reduction (for example see Youngblut et al., 2016), here, we provide an overview of the emerging biotechnological applications of (per)chlorate respiration and the underlying organisms and enzymes to environmental and biotechnological industries.
\end{abstract}

Keywords: perchlorate; chlorate; microbial perchlorate reduction; perchlorate bioremediation; bio-souring control; bioreactor hygiene controls; aeration enhancement

\section{Introduction}

The oxyanions of chlorine, perchlorate $\left(\mathrm{ClO}_{4}^{-}\right)$, and chlorate $\left(\mathrm{ClO}_{3}{ }^{-}\right)$, are highly soluble, strong oxidants that are deposited in the environment through both anthropogenic and natural processes [1-8]. Perchlorate is a common commodity chemical with a diverse range of industrial uses, ranging from pyrotechnics to lubricating oils [4], but it is predominantly used as an energetics booster or oxidant in solid rocket fuels by the munitions industry [4,9-11]. Although being a powerful oxidant, under most environmental conditions perchlorate is highly stable on account of the high energy of activation that is associated with its reduction [1,9]. Perchlorate is toxic to humans as it inhibits the uptake of iodine by the thyroid gland [12], disrupting the production of thyroid hormones, potentially leading to hypothyroidism $[13,14]$. For humans, oral ingestion is the primary source of perchlorate exposure as contamination is widespread in soil, fertilizers, and groundwater, allowing it to readily move into our food chain [15].

In contrast, chlorate is far more chemically reactive than perchlorate [16]. It is currently used to produce chlorine dioxide in bleaching and disinfection processes [17] and as a precursor for the 
manufacture of perchlorate. Historically, it was widely used as the active component of herbicides during the early twentieth century $[18,19]$. Chlorate is also toxic to humans causing oxidative damage to red blood cells, resulting in methemoglobin formation [20,21]. In both plant and microbial cells, chlorate can be a substrate for respiratory or assimilatory nitrate reductases, which reduce it to chlorite $\left(\mathrm{ClO}_{2}{ }^{-}\right)$[22], a compound with demonstrated broad-spectrum biocidal activity against Gram-negative and Gram-positive bacteria [23-28], bacteriophages [29], fungi [23], and algae [25]. Because of this, chlorite is often used to treat freshwater copepod parasites [30], and as an active ingredient in topical wound treatments.

In the 1920's, bacteria were discovered that used chlorate, (and presumably perchlorate, although this is not a prerequisite [18]) as a terminal electron acceptor for anaerobic energy production [31]. Recent studies have identified the molecular mechanisms underlying this unique biochemistry (Figure 1) [9,18,19]. Dissimilatory (per)chlorate reducing bacteria (DPRB) use a highly conserved perchlorate reductase, PcrABC, to reduce perchlorate to chlorate and subsequently chlorite. The chlorite is rapidly removed by another highly conserved enzyme, chlorite dismutase (Cld), to produce molecular oxygen $\left(\mathrm{O}_{2}\right)$ and innocuous chloride $\left(\mathrm{Cl}^{-}\right)[9,18,19,32]$. The oxygen that is produced is then respired by the same organism, generally through the use of a high-affinity cytochrome $c b b 3$-oxidase $[18,19]$. Specialized dissimilatory chlorate-reducing bacteria (DCRB) respire only chlorate and not perchlorate using an analogous pathway involving chlorite and Cld, but the chlorate is initially reduced via a specialized chlorate reductase (ClrABC), a structurally and evolutionarily distinct enzyme from the PcrABC that can reduce chlorate but not perchlorate [33-37]. Owing to the unique ability to degrade (per)chlorate and generate molecular oxygen under anaerobic conditions, DPRB, perchlorate reductase, chlorate reductase, and chlorite dismutase provide innovative solutions to outstanding problems in current industrial processes. In this review, we provide an overview of the potential applications of microbial (per)chlorate reduction, and the underlying genes and enzymes. The taxonomy, evolution, biochemistry, and physiology of microbial (per)chlorate reduction are beyond the scope of this review and have been described in detail elsewhere $[18,19]$.

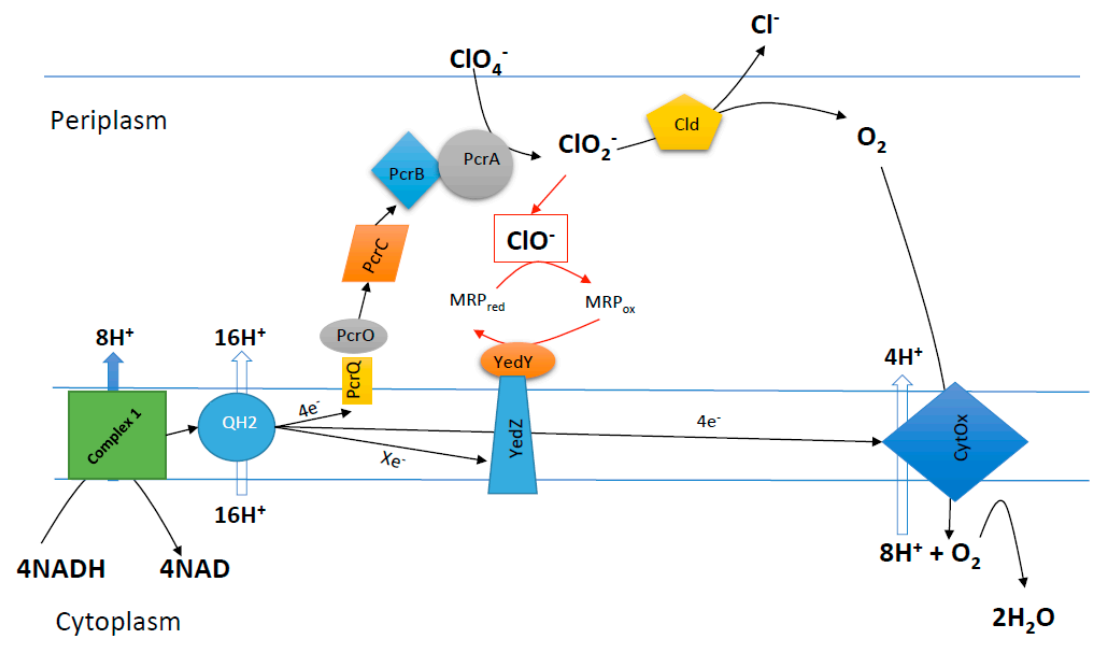

Figure 1. A schematic of the current model for the biochemical pathway of perchlorate reduction. As part of this pathway, hypochlorite $\left(\mathrm{ClO}^{-}\right)$is inadvertently produced at the chlorite dismutase. Perchlorate reducing bacteria have evolved a detoxification process based on a methionine rich peptide that chemically reacts with $\mathrm{ClO}^{-}$to produce methionine sulfoxide, which is subsequently re-reduced by the methionine sulfoxide reductase (YedY) using reducing equivalents from the quinone oxidoreductase (YedZ). QH—quinone pool; Pcr-Perchlorate reductase; Cld-Chlorite dismutase; CytOx-Cytochrome oxidase; and, MRP - methionine rich peptide. For the biochemical pathway of chlorate reduction, PcrABC is replaced by chlorate reductase $\mathrm{Cl} A \mathrm{ABC}$, however, the process by which $\mathrm{Cl} A \mathrm{ABC}$ receives electrons from the quinone pool is currently not well understood. 


\section{2. (Per)chlorate Bioremediation}

The primary application of microbial (per)chlorate reduction is the bio-attenuation of perchlorate-contaminated water sources [38]. Bioremediation of perchlorate can be much more effective than other remediation strategies, as perchlorate is completely and irreversibly reduced to innocuous chloride [38]. For example, although ion exchange based technology is a widely used and effective method for perchlorate removal, it does not uniquely bind to perchlorate, rather the ion exchange resins also bind other common co-contaminating anions such as nitrate which are often present in concentrations several orders of magnitude higher than perchlorate. As such, much of the ion exchange capacity is lost in binding these analogous compounds [38]. Furthermore, ion exchange technologies concentrate perchlorate and other ions into a recalcitrant brine, which often poses disposal issues in its own right $[19,38-40]$. In contrast, perchlorate metabolism by DPRB completely converts perchlorate into innocuous chloride [38]. This can be used as an independent treatment strategy or can be applied in combination with ion exchange methods using halophilic DPRB [41-44] or salt-tolerant communities [39,45-47] to treat perchlorate-laden waste brines that are extracted from ion exchange resins that would otherwise pose significant health and disposal issues.

Perchlorate bioremediation can be achieved in-situ or ex-situ using various types of bioreactors. While laboratory-scale autotrophic reactors using hydrogen [48-51], reduced iron [52], or sulfur compounds [53] as the electron donor have been developed, most industrial-scale fixed or fluidized-bed reactors are operated as heterotrophic reactors using either simple alcohols or acetate as the electron donor [19,54]. Among the different types, fluidized-bed heterotrophic (with ethanol as the electron donor) bioreactors have emerged as the most successful for perchlorate treatment with capacities up to $34 \times 10^{6}{\mathrm{~L} \cdot \mathrm{day}^{-1}}^{-1}$, reducing perchlorate concentrations to below $6 \mathrm{ppb}\left(6 \mu \mathrm{g} \cdot \mathrm{L}^{-1}\right)$, the maximum concentration limit that is allowed in the state of California [19,55].

Conventional bioreactors always depend on the continuous addition of a chemical electron donor and are subject to bio-fouling issues due to microbial growth [54,56-58]. Furthermore, disposal of the excess biomass generated represents a significant operational cost of the treatment process, while any residual labile electron donor in the reactor effluent can stimulate microbial growth in water distribution systems and contribute to the formation of toxic trihalomethanes during disinfection by chlorination [59]. These issues led to the proposal of a diversity of alternative advanced reactor designs. An innovative and unorthodox bioreactor concept was developed in 2007 based on the electrochemical stimulation of microbial perchlorate reduction $[56,60,61]$ (Figure 2). In these packed-bed bioelectrical reactors, DPRB use electrons that are provided through a negatively charged cathode set at a redox potential of $500 \mathrm{mV}$ as an electron donor. Preliminary studies suggested that electrons were either directly consumed off the electrode surface or indirectly through the use of anthraquinone-2,6-disulfonate as a recyclable electron shuttle [56,62]. However, subsequently, it was demonstrated that these reactors did not function mechanistically as initially perceived [62]. Remarkably, it was shown that living DPRB cells were not required for perchlorate reduction in the bioelectrical reactors. Rather, catalytic amounts of oxygen contaminating the bioelectrical packed-bed reactors reacted with electrochemically reduced anthraquinone-2,6-disulfonate to form superoxide and hydrogen peroxide, leading to DPRB cell lysis and active enzyme release [62]. The observed perchlorate reduction and removal was primarily mediated through interconnected enzymatic electrocatalysis mechanisms, in which the cathode-reduced anthraquinone-2,6-disulfonate functioned as a direct electron donor for the perchlorate reductase enzyme PcrAB that was released from the dying lysing microbial cells $[56,62]$. While the underlying mechanism of perchlorate attenuation was not dependent on living cells, the technology still shows great promise and could be improved by the use of nanocarbon conductive interlinks between the electrode surface and the cell or by the identification of DPRB that can use electrons directly off the electrode surface similar to the mechanism used by a diversity of iron reducing species $[63,64]$. Alternatively, the redox potential on the cathode could be increased to allow for electrochemical $\mathrm{H}_{2}$ generation, which could support an autotrophic DPRB population. Although further work is needed to develop the technology to commercial application, 
the advantages are substantial in being able to control the rate of metabolism and perchlorate treatment independently from biomass growth (Figure 2).

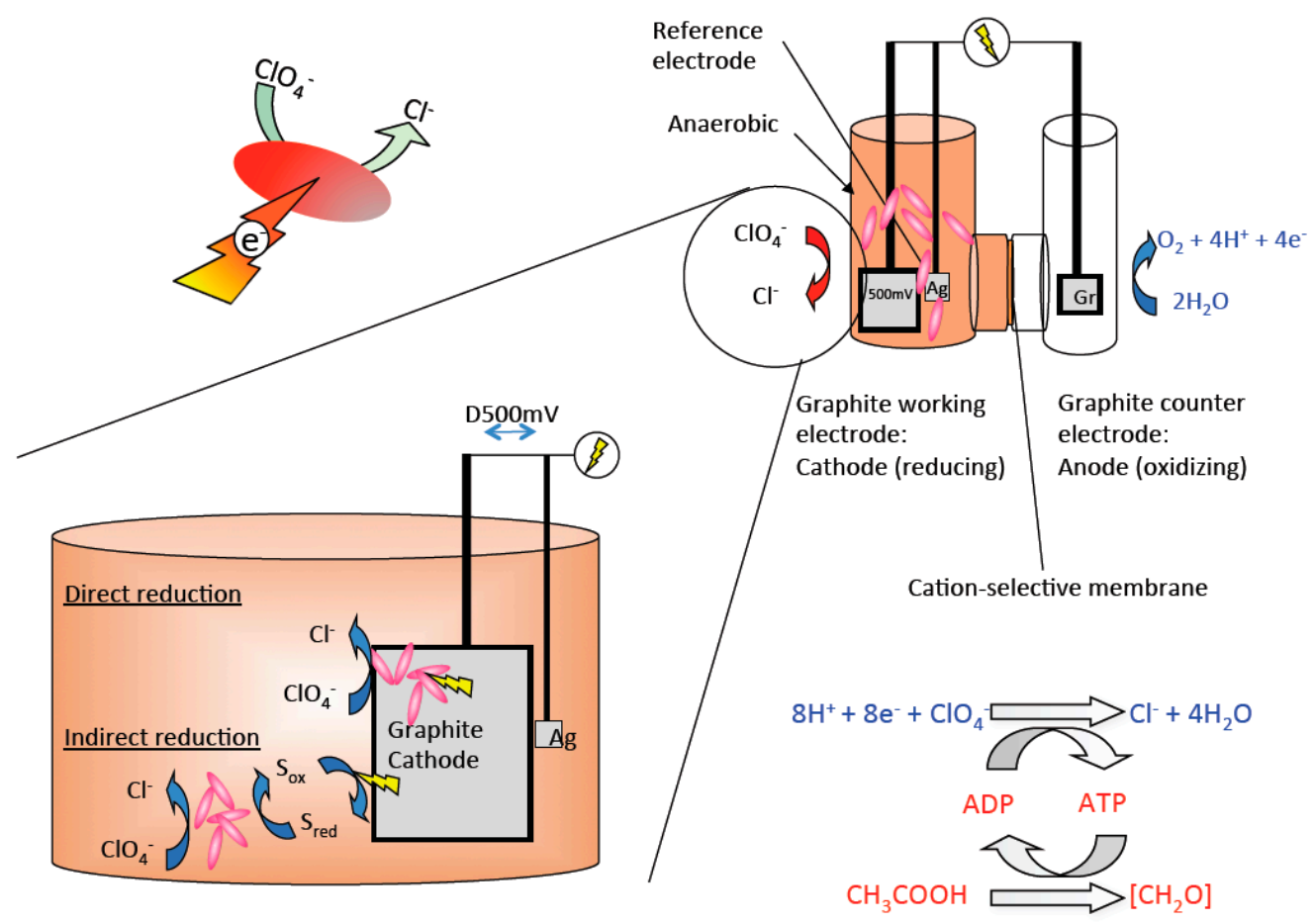

Figure 2. A schematic diagram of a packed-bed bioelectrical reactor for perchlorate bioremediation. DPRB use electrons provided through a negatively charged cathode as the direct or indirect (mediated by an electron shuttle) electron donor to reduce perchlorate to innocuous chloride. S ox-oxidized electron shuttle; $\mathrm{S}$ red-reduced electron shuttle.

\section{Enzymatic Bioassay for the Detection of Perchlorate}

Ion chromatography and mass spectrometry are commonly used for the detection and quantification of perchlorate in environmental samples [65-67]. Although sensitive, these methods are slow, costly, and require specialized personnel and laboratories. Therefore, an enzymatic bioassay that offers a cost-effective alternative with the potential for high throughput application was developed using a mixture of purified perchlorate reductase (PcrAB), nicotine adenine dinucleotide (NADH), and the electron shuttle phenazine methosulfate (PMS) [68,69]. In this bioassay, PMS mediates the transfer of electrons from NADH to PcrAB, which subsequently reduces perchlorate to chlorite (Figure 3). The enzymatically produced chlorite is subsequently dismutated by Cld to produce $\mathrm{O}_{2}$, which chemically reacts with the PMS resulting in further NADH oxidation. This additional PMS cycle provides an effective twofold signal amplification (Figure 3). The perchlorate concentration is indirectly measured by the oxidation of $\mathrm{NADH}$, which is monitored as absorbance changes at $340 \mathrm{~nm}[68,69]$. A perchlorate detection range of $2-17,000 \mathrm{ppb}\left(\mu \mathrm{g} \cdot \mathrm{L}^{-1}\right)$ was achieved when the bioassay was coupled with a solid-phase extraction step to purify and concentrate the perchlorate $[68,69]$. This step, based on styrene divinyl benzene syringe columns pretreated with decyltrimethylammonium bromide (DTAB), allowed for the selective extraction and concentration of perchlorate from solutions with numerous co-occurring ions including nitrate, phosphate, sulfate, iron, and chloride [68,69]. Although this bioassay is sensitive to air due to the slow oxygen-induced inactivation of perchlorate reductase, this issue was avoided by covering all of the reactions with mineral oil [69]. Alternatively, an oxygen insensitive enzyme, such as suitable nitrate reductase that is capable of reducing perchlorate, could conceptually be used to replace the PcrAB, although this might significantly impact the assay lower limit of detection. Youngblut et al. [32] recently demonstrated that the PcrAB is a specialized member 
of the DMSO reductase superfamily, with a relatively high perchlorate affinity $\left(K_{M}=6 \mu \mathrm{M}\right)$, unlike the closely related nitrate reductase, which has a much lower affinity for perchlorate $\left(K_{\mathrm{M}}=1.1 \mathrm{mM}\right)$.

\section{A bioassay for perchlorate}

Monitor NADH concentration at $340 \mathrm{~nm}$

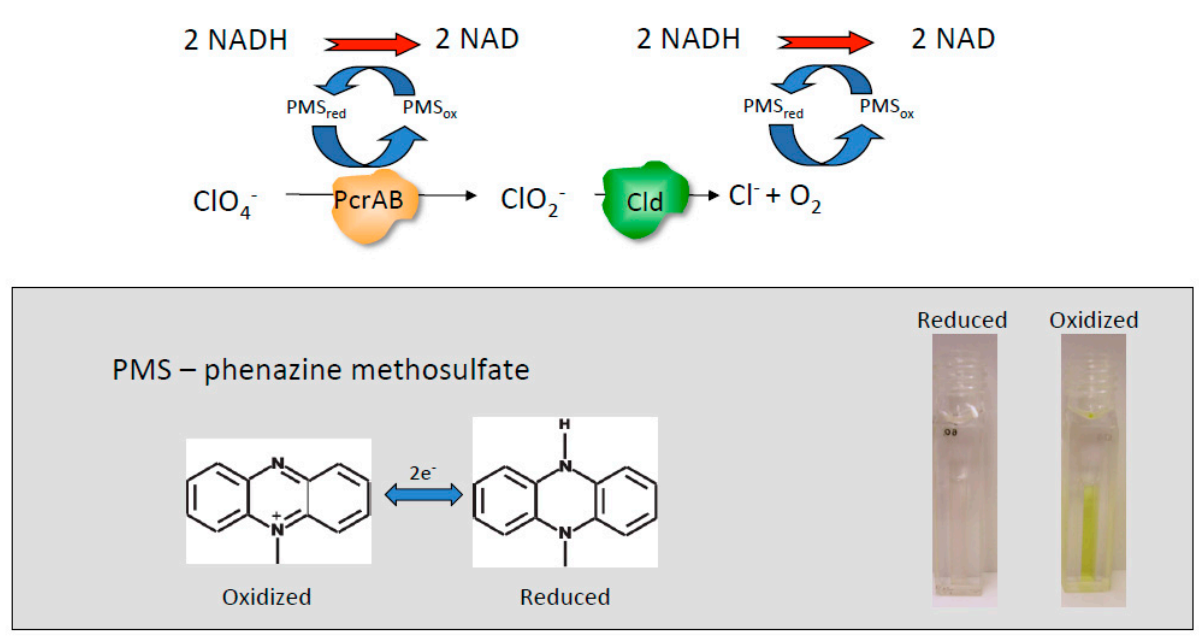

Figure 3. Schematic for the high throughput bioassay (with a perchlorate detection range of 2-17,000 ppb) using perchlorate reductase (PcrAB), chlorite dismutase (Cld), nicotine adenine dinucleotide (NADH), and the electron shuttle phenazine methosulfate (PMS).

\section{Bioeletrochemical $\mathrm{O}_{2}$ Production from Perchlorate}

Perchlorate has been detected and inferred on Mars at concentrations between $0.5 \%$ and $1 \%$ [70,71] Similarly, perchlorate has also been detected in lunar and meteorite samples [72], suggesting its prevalence across the solar system and possibly beyond. Due to unrestricted UV radiation and the lack of biotic perchlorate diagenesis processes, the quantity of perchlorate in the surface regolith of Mars is three to four orders of magnitude higher when compared with soils on Earth, and offers an attractive resource for human exploration and survival. Traditionally, perchlorate is used as an energetic booster or oxidant in solid rocket fuel. However, perchlorate on Mars could also serve as a source of $\mathrm{O}_{2}$ for human consumption [73]. For example, humans respire 550-650 L of oxygen per day. Based on the estimated mass fraction of perchlorate in Martian regolith, a daily supply of oxygen for one astronaut could be obtained by the complete dissociation of perchlorate contained in $60 \mathrm{~kg}$ of regolith. Perchlorate can be extracted from Martian regolith easily with water, which can be recycled for reuse with minimal effort. Because of the large molecular volume and single anionic charge, perchlorate has a low affinity for cations, and, as a result, perchlorate salts are generally highly soluble and completely dissociate into perchlorate and the relevant counter ion in aqueous solutions. Furthermore, perchlorate does not sorb to any significant extent to soils or sediments and, in the absence of any biological interactions, its mobility and fate are largely influenced by the hydrology of the environment [74]. As such, the extraction of perchlorate laden rock simply requires water.

The method of $\mathrm{O}_{2}$ production from the extracted perchlorate takes advantage of electrochemistry combined with enzymatic reduction (Figure 4) previously developed for microbial perchlorate attenuation in a bioelectrical reactor (BER) [56]. Electrochemical consumption of perchlorate in the cathodic chamber mediated by an active perchlorate reductase enzyme can be coupled to electrolysis of water releasing pure $\mathrm{O}_{2}$ with no contaminating gases in the anodic chamber. Furthermore, because 
water is formed in the cathodic chamber at a rate that is identical to that consumed in the anodic chamber (Reactions 1-3) (Figure 4), the system is not limited by water availability.

$$
\begin{gathered}
\text { Reaction 1: } 4 \mathrm{H}_{2} \mathrm{O} \rightarrow 2 \mathrm{O}_{2}+8 \mathrm{H}^{+}+8 \mathrm{e}^{-} \\
\text {Reaction 2: } 8 \mathrm{H}^{+}+8 \mathrm{e}^{-}+\mathrm{ClO}_{4}^{-} \rightarrow \mathrm{Cl}^{-}+4 \mathrm{H}_{2} \mathrm{O} \\
\text { Combined Reaction 3: } \mathrm{ClO}_{4}^{-} \rightarrow \mathrm{Cl}^{-}+2 \mathrm{O}_{2}
\end{gathered}
$$

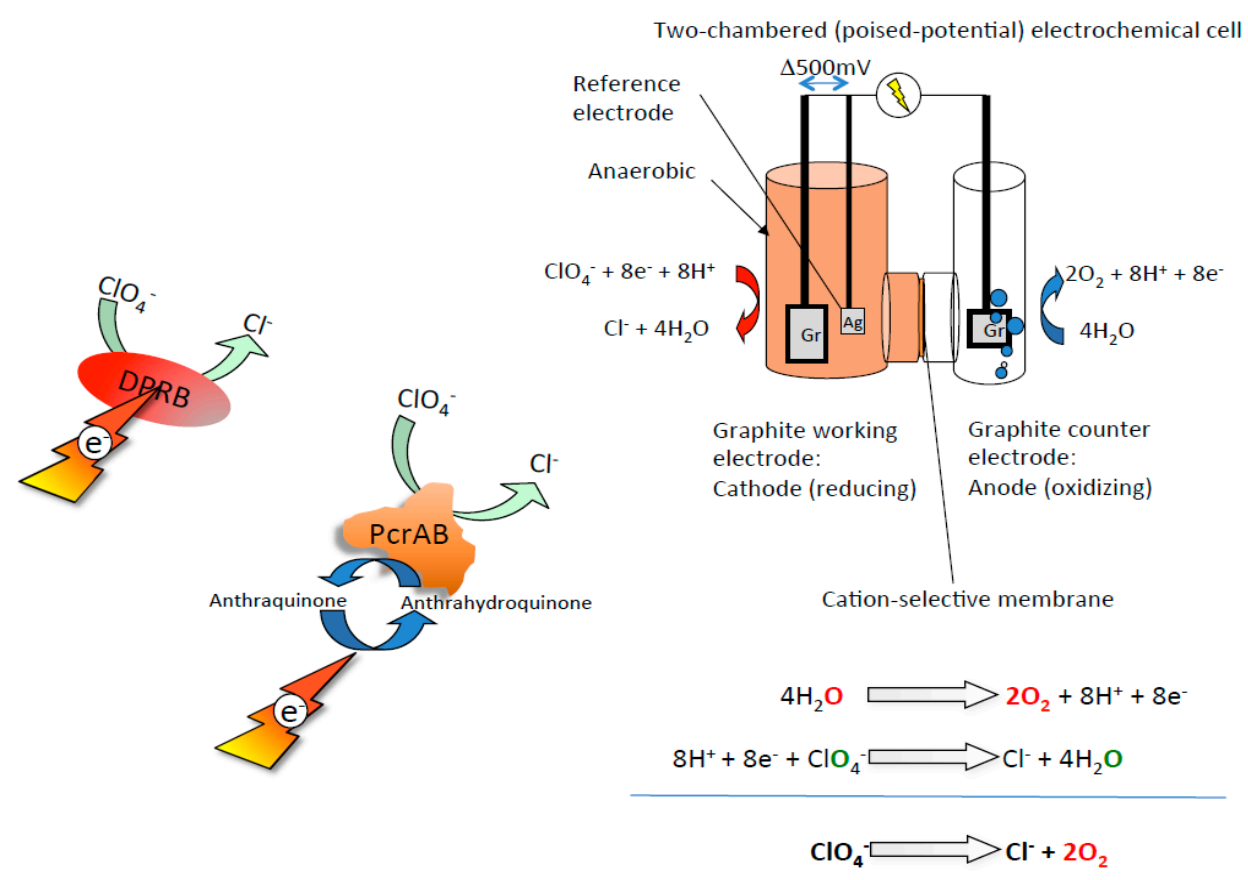

Figure 4. A schematic diagram of a bioelectrical reactor developed for bioelectrochemical oxygen production from perchlorate. Electrochemical consumption of perchlorate in the cathodic chamber mediated by active perchlorate reductase enzymes or lysed dissimilatory perchlorate-reducing bacteria (DPRB) cells are coupled to electrolysis of water releasing pure $\mathrm{O}_{2}$ in the anodic chamber.

The technology is composed of a simple poised potential electrochemical cell containing a cathode and an anode. The redox potential on the cathode can be set at $500-750 \mathrm{mV}$ relative to a reference electrode. The anode voltage is left free floating at $\geq 1.5$ volt, while power can be provided through a photovoltaic cell. The cathode chamber is filled with an aqueous extract of regolith containing perchlorate and amended with pure enzyme or lysed cells with demonstrated perchlorate reduction capacity. The cathode chamber can be further amended with a soluble electron shuttle, such as 2,6-anthraquinone disulphonate $(100 \mu \mathrm{M})$, to mediate electron transfer from the electrode surface to the active enzyme. Preliminary studies demonstrated the bioelectrochemical reduction of $\sim 1 \mathrm{mM}$ perchlorate over $8 \mathrm{~h} \mathrm{[56],} \mathrm{which} \mathrm{equates} \mathrm{to} \mathrm{the} \mathrm{production} \mathrm{of} \sim 2 \mathrm{mM} \mathrm{O}_{2}$ (or $\sim 45 \mathrm{~mL}$ from a $1 \mathrm{~L}$ bioreactor), suggesting that some process optimization is required to achieve a goal of 550-650 L of oxygen per day. However, the rate of oxygen production is directly correlated to the rate of perchlorate reduction, which is a function of enzyme concentration in the cathodic chamber, thus it is easy to envision straightforward approaches for rate improvement. The anodic chamber is filled with water and the electrical requirements can either be supplied from photovoltaic cells or from alternative electrical sources. When the water content of the anode chamber is depleted, it can be refilled with water produced in the cathode chamber. While this process may not be suitable to scale up to satisfy the sole needs of a human colony, it could offer an emergency $\mathrm{O}_{2}$ alternative, taking advantage of the natural resources of the planet. 


\section{Oil Reservoir Bio-Souring Control}

Off-shore petroleum extraction often involves injection of sulfate-rich $(\sim 28 \mathrm{mM})$ seawater into the oil reservoir, which increases the reservoir pressure and facilitates crude oil recovery $[75,76]$. However, this practice frequently leads to the bio-generation of hydrogen sulfide $\left(\mathrm{H}_{2} \mathrm{~S}\right)$ by sulfate reducing microorganisms (SRM) [76,77]. This phenomenon, termed bio-souring, poses significant health and operational risks due to the toxic, explosive, and corrosive nature of hydrogen sulfide gas, and has an estimated associated annual cost of $\$ 90$ billion globally $[19,78]$. Presently, the most common practice for bio-souring control is the addition of nitrate into the injected seawater to stimulate nitrate respiration $[76,77,79,80]$. Microbial nitrate reduction is thermodynamically more favorable than microbial sulfate reduction $\left(\mathrm{NO}_{3}{ }^{-} / \mathrm{N}_{2} \mathrm{E}^{\circ \prime}=+750 \mathrm{mV}, \mathrm{SO}_{4}^{-} / \mathrm{HS}_{2} \mathrm{E}^{\circ \prime}=-217 \mathrm{mV}\right)$, and, as such, should bio-competitively exclude sulfate reduction $[76,79,80]$. However, while bio-competitive exclusion may effectively reduce souring in some natural environments, the favorable thermodynamics of nitrate reduction does not exclude the potential for the co-occurrence of sulfate reduction if the electron donor is saturating [81], as is the case in an oilfield. In addition, sulfate reduction can persist in deeper reservoirs as nitrate penetration is limited due to rapid depletion through microbial respiration, as seawater is often a rich source of nitrate reducing organisms [16,76,79,82]. Furthermore, many SRM, including Desulfovibrio spp., Desulfobulbus spp., and Desulfomonas spp., can alternatively use nitrate as a terminal electron acceptor, foreshadowing rapid SRM activity and $\mathrm{H}_{2} \mathrm{~S}$ rebound during any interruption of nitrate treatment [83].

Recent studies have exploited perchlorate and DPRB as an alternative method for oil reservoir bio-souring control. Perchlorate treatment has several advantages over nitrate (Figure 5). First, microbial perchlorate respiration is thermodynamically more favorable $\left(\mathrm{E}^{\circ \prime}=+797 \mathrm{mV}\right)$ than either nitrate or sulfate reduction $[18,19,75]$, therefore ensuring the bio-competitive exclusion of SRM by DPRB. Second, sulfide causes electron transport chain short-circuiting in DPRB, in which the perchlorate reductase directly oxidizes sulfide to produce elemental sulfur [84]. Due to the highly conserved nature of the perchlorate reductase, all DPRB tested to date rapidly and preferentially oxidize sulfide, even in the presence of labile physiological electron donors (e.g., acetate, lactate etc.) $[75,84]$. The DPRB retain the ability to grow on other electron donors once the sulfide is completely biologically removed [75,84]. Finally, perchlorate acts as a competitive inhibitor of the ATP sulfurylase, which is a highly conserved key enzyme in the sulfate reduction pathway [78]. A proof-of-concept study of a flow-through column system mimicking an oil reservoir environment with the potential to sour has confirmed dramatic SRM activity inhibition by the addition of perchlorate [16] at concentrations as low as $3.5 \mathrm{mM}[85]$.

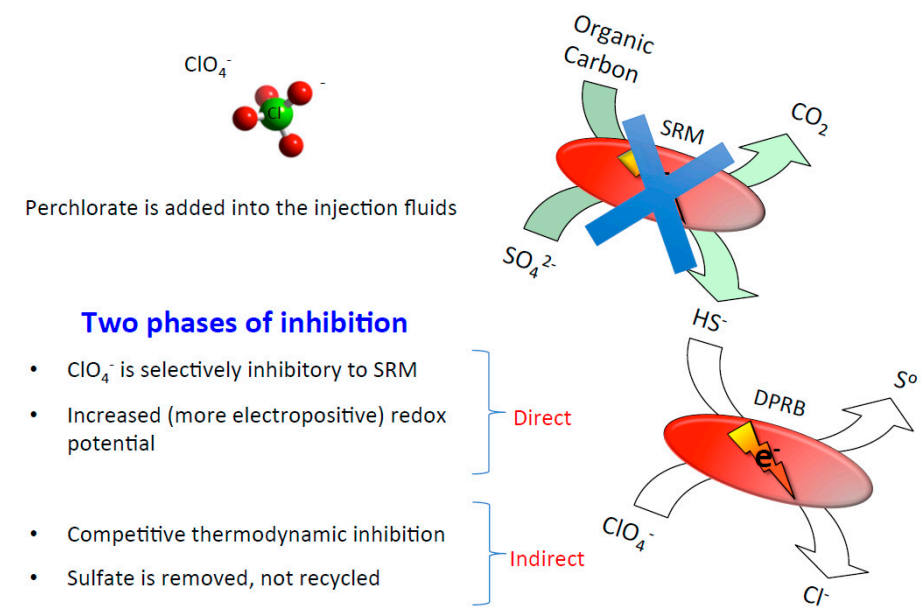

Figure 5. A model illustrating different modes of inhibition of sulfate reducing microorganisms (SRM) by perchlorate and dissimilatory perchlorate-reducing bacteria (DPRB). 


\section{Xenobiotic Bioremediation by DPRB and DCRB}

Anthropogenic activities, such as industrial discharges and accidental spills, often result in the release of highly toxic xenobiotics, such as benzene, toluene, ethylbenzene, or xylene (BTEX) into groundwater, soil, or sediments [86-88]. Aerobic microorganisms, especially Pseudomonas species, utilize oxygen as a co-substrate for oxygenase enzymes to effectively cleave chemically stable aromatic rings $[89,90]$. However, this combined with the utilization of $\mathrm{O}_{2}$ as an electron acceptor for respiration leads to a rapid depletion of oxygen. As such, the contaminated environment becomes anoxic and dominated by anaerobic microbial metabolism [91]. Under anoxic conditions, microbial metabolisms dependent on energy consuming reductive de-aromatization steps to cleave the ring [92,93], and the rate of degradation is significantly slower than when $\mathrm{O}_{2}$ is available [94].

Owing to their unique ability to generate molecular oxygen under anaerobic conditions, it had long been postulated that DPRB and DCRB are capable of stimulating oxygenase-dependent anaerobic metabolisms [19,95-97]. This was first shown in anoxic co-cultures of DPRB with obligate aerobic hydrocarbon utilizing Pseudomonas spp. [95,96]. In these studies, degradation of benzene and naphthalene was demonstrated under anoxic conditions when the cultures were amended with chlorite. The chlorite was directly dismutated into $\mathrm{O}_{2}$ and $\mathrm{Cl}^{-}$by the active DPRB (Figure 6) and the biogenic $\mathrm{O}_{2}$ was subsequently available for the aerobic Pseudomonas to use as a co-substrate and an electron acceptor for the hydrocarbon metabolism in an oxygenase-dependent manner. An expansion of these studies showed that degradation of both monoaromatic and polycylic aromatic hydrocarbons could be stimulated in contaminated anoxic sediment upon bioaugmentation with DPRB and addition of chlorite [95]. Subsequent studies have similarly demonstrated that methane degradation can be correspondingly stimulated in a co-culture of an aerobic methanotroph with a DPRB [98].

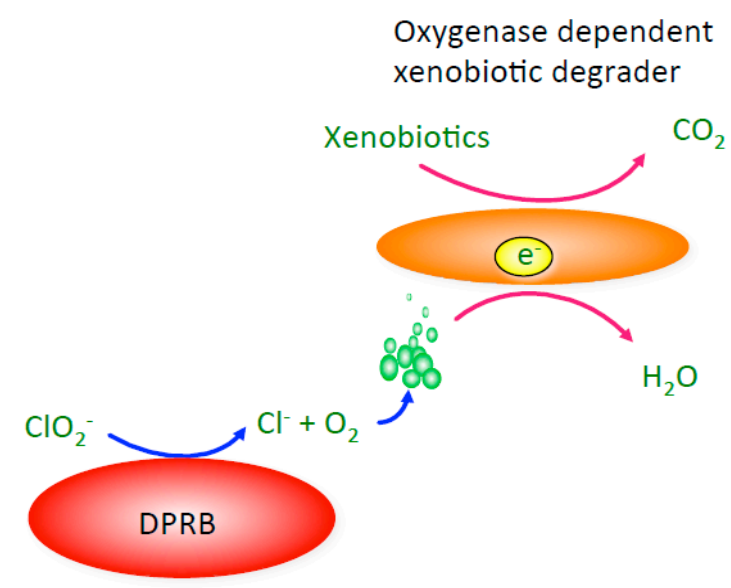

Figure 6. A model of oxygenase-dependent degradation for a xenobiotic degrading co-culture in the absence of $\mathrm{O}_{2}$. Pre-requisite oxygen is supplied to the obligately aerobic xenobiotic degrading organism by the dissimilatory (per)chlorate reducing bacterium (DPRB) as a result of the dismutation of added chlorite.

These findings led to the postulation that DPRB, with the appropriate gene content, may exist that can completely catabolize xenobiotics independently under anoxic conditions in an oxygenase-dependent manner using perchlorate as their sole electron acceptor (Figure 7). Indeed, recent studies have confirmed that the DPRB Arcobacter sp. CAB and the DCRB Dechloromarinus chlorophilus NSS use aerobic pathways under anaerobic conditions to couple (per)chlorate reduction to the degradation of such aromatic compounds as catechol, phenylacetate, and benzoate [41,42]. Under these conditions, some of the biogenic $\mathrm{O}_{2}$ is reused by the cell for the appropriate catabolic pathway (Figure 7). Remarkably, in some of these organisms, internal oxygen consumption is not a prerequisite for aromatic compound degradation coupled to (per)chlorate 
reduction, as demonstrated by the ability of Sedimenticola selenatireducens CUZ to utilize both anaerobic and aerobic catabolic pathways to degrade phenylacetate and benzoate during (per)chlorate respiration [41]. The production of oxygen by DPRB and DCRB makes these organisms excellent candidates for the bioremediation of a broad diversity of recalcitrant xenobiotic compounds under anoxic or oxygen-limiting conditions, both in situ and in bioreactors.

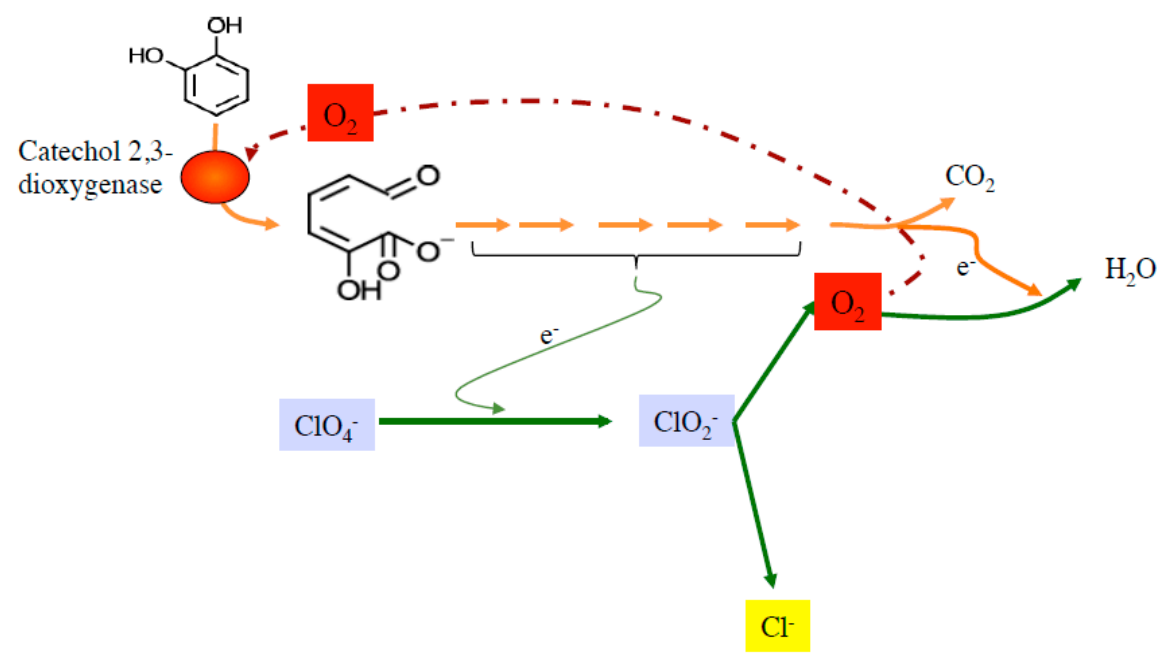

Figure 7. A simplified model illustrating the oxygenase-dependent, anaerobic catechol degradation pathway in the DPRB Arcobacter sp. CAB. Green, orange, and red arrows indicates perchlorate reduction pathway, catechol degradation pathway, flow of oxygen, or electrons, respectively.

\section{Genetic Optimization of DPRB and DCRB}

The recent development of genetic systems for both DPRB and DCRB allows for the construction of (per)chlorate-reducing organisms with improved phenotypic characteristics [34-36,99]. Marker-less gene deletion strains can now be generated by antibiotic selection via suicide plasmid genomic integration, and subsequent plasmid excision via sucrose $(\operatorname{sac} B)$ or streptomycin $(r p s L)$ counter-selection [34-36,99]. In addition, gene complementation and enzyme over-expression can be achieved with the pSC101 and pBBR1MCS series of broad range plasmids [34-36,99]. Furthermore, bar-coded transposon mutant libraries of the DPRB Azospira suillum PS and the DCRB Pseudomonas stutzeri PDA are available for rapid gene-fitness profiling under diverse conditions [36,100]. These bar-coded transposon mutant libraries allow for rapid beneficial or detrimental gene identification under different growth conditions (e.g., high salinity, high temperature, high pressure, etc.). Equipped with these molecular tools, engineers have been able to manipulate DPRB and DCRB genomes according to their fitness profiles to achieve desired phenotypes with potential biotechnological application $[36,100]$. As an example, reactive chlorine species such as chlorite and hypochlorite are produced as toxic intermediates during (per)chlorate respiration. Melnyk and co-workers were able to construct a strain of $A$. suillum that was resistant to reactive chlorine species by knocking out the anti-sigma factor $n r s F$, which is a repressor of the sigma factor sig $F$ that activates the expression of hypochlorite scavenging methionine-rich peptide ( $\mathrm{mrpX}$ ) and methionine sulfoxide reductase (yedY1) [100]. The $n r s F$ deletion strain showed an increased tolerance and enhanced growth rate with high concentration of chlorate, presumably due to heightened resistance to reactive chlorine species produced as part of the respiratory pathway [100].

\section{Chlorite Mediated Bioreactor Hygiene Control}

The biotechnology industry uses living organisms for the development or biotransformation of its products from raw materials. In 2015, this industry generated $\$ 107.7$ billion of revenue in 
the United States (US) alone and has an estimated global market value of $\$ 890$ billion (www.statista. com/topics/1634/biotechnology-industry). Bioprocessing and biotransformation with bioreactors frequently suffer from contamination with environmental microbes or bacterial phages [101-104]. Robust long-term operations often rely on costly antibiotic addition, which is economically infeasible for bio-commodity production. A proposed alternative is the use of chlorite and Cld as a biocide/biocide-resistance system for bioprocessing hygiene control. Chlorite is a low-cost biocide with activity against a broad range of microorganisms and viruses [23-29], and chlorite dismutase provides specific resistance to chlorite. For example, under aerobic conditions, the DPRB Azospira suillum PS grew normally in the presence of $40 \mu \mathrm{M}$ chlorite, while a cld gene deletion mutant failed to grow (Coates lab, unpublished observations). Additionally, heterologous expression of Cld in non-(per)chlorate reducing Shewanella oneidensis MR-1 protected the strain against chlorite toxicity (Coates lab, unpublished observations). In theory, it should be possible to construct a chlorite hyper-resistant industrial strain by the heterologous expression of Cld. However, one key difficulty is balancing the optimization of Cld activity with chlorite resistance. High Cld activity would lead to rapid chlorite removal, decreasing the selection against contaminant strains. Future studies could utilize directed evolution approaches to optimize and construct a Cld mutant that has low enzymatic activity, but can still confer resistance to the production strain.

\section{Chlorite Mediated Aeration Enhancement}

The physical properties of molecular oxygen, such as its low aqueous solubility $(40 \mathrm{mg} / \mathrm{L}$ at $1 \mathrm{~atm}, 25^{\circ} \mathrm{C}$ ) and low mass transfer rate through the air-water interface, impose technical challenges in both laboratory enzymology experiments and industry scale bioprocessing [105-110]. Owing to the large oxygen demand in high cell density bioreactors, operators sometimes use expensive pure oxygen instead of air for aeration, along with an increased pressure and agitation rate to enhance the oxygen mass transfer [107]. Dassama and co-workers demonstrated that the addition of purified Cld and chlorite in aqueous solution resulted in a "burst" of oxygen generation of $>5 \mathrm{mM}$ in less than $1 \mathrm{~ms}$ [109]. This efficient enzymatic oxygen-generation system has been applied to increase the yield of unstable (half-life $<1-10 \mathrm{~s}$ ) oxygenated intermediates [109], and to elucidate the biochemical mechanisms of oxygenases and oxidases [108,111,112]. The addition of purified Cld is implausible in industry-scale bioprocessing plants due to the large volume of industrial bioreactors and the high cost that is associated with Cld purification. However, the aeration problem could be solved by expressing Cld in the process organisms, which, in combination with chlorite addition, results in oxygen generation. Chlorite is extremely cheap (approximately $\$ 1$ per $\mathrm{kg}$ ), and only requires mild agitation as a result of its high solubility in water. Preliminary evidence of the potential for this approach was apparent in the demonstration of enhanced oxygenase-dependent benzene and naphthalene degradation under anaerobic conditions by the addition of chlorite and DPRB [95,96]. Further studies are needed for the materialization and validation of this approach.

\section{Gas Gangrene Treatment}

A major medical problem in deep tissue wound therapy relates to the prevention and treatment of gas gangrene. At a basic level, gas gangrene can result from development of anaerobic conditions in deep wounds and infection by obligatory anaerobic Clostridia species producing necrotizing tissue toxins. Gas gangrene is generally fatal if left untreated. Furthermore, many Clostridia species have developed resistances to a broad range of antibiotics, necessitating the application of alternative treatment technologies. These are often complex, expensive, and of limited success. Apart from amputation of the infected region, current treatments of gas gangrene involve cumbersome hypobaric chambers to increase oxygen levels in infected tissue or "maggot therapy", in which live maggots are sutured into the wound to graze on the necrotic tissue and Clostridium cells.

A novel alternative treatment was proposed that takes advantage of the activity of Cld purified from DPRB, which produces oxygen in copious quantities from aqueous solutions of chlorite, stored 
as a dry stable sodium salt under oxic or anoxic conditions. Studies have shown that the purified enzyme is stable and functions optimally at circumneutral $\mathrm{pH}$ and $35^{\circ} \mathrm{C}$ [113]. From a very simplistic perspective, one can envision the mechanistic basis of such a treatment, whereby the oxygen produced and evolved as gaseous $\mathrm{O}_{2}[18,96]$ could inhibit the development and progression of the Clostridial gangrenous infection in deep wounds over the long term (Figure 8). Furthermore, chlorite itself has known biocidal activity against a broad range of microorganisms and viruses [23-29], and as such would have an immediate antibiotic effect prior to the long term development of oxic conditions.

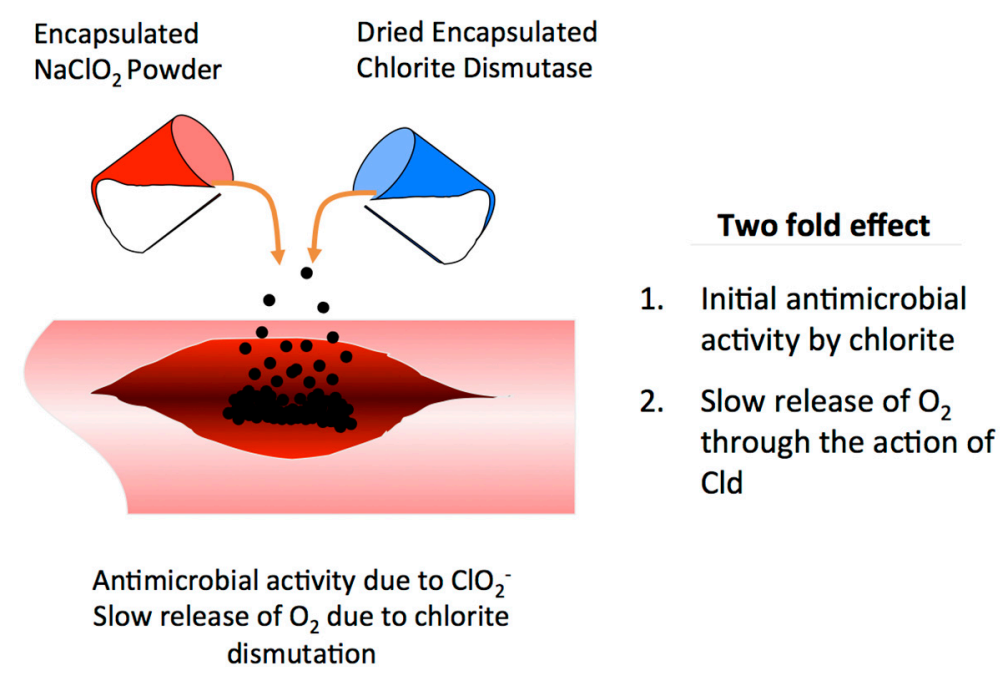

Figure 8. Chlorite dismutase (Cld) and chlorite as a novel alternative treatment for gas gangrene.

\section{Conclusions}

Exciting research in the field of microbial (per)chlorate reduction in the past 20 years has revealed the unique physiological and biochemical characteristics of microbial (per)chlorate reduction and its associated enzymatic and genetic mechanisms. This understanding provides many opportunities to leverage the novel capabilities of these organisms and apply this knowledge to solve outstanding problems in the environmental and biotechnological industries. Aside from perchlorate bioremediation, many of the other topics outlined here require commercial validation, while others are still at the preliminary proof-of-concept stage. Such early stage technologies offer excellent prospects for researchers and industrialists alike, who wish to contribute to the realization and translation of these concepts.

Acknowledgments: Funding for the investigation of microbial (per)chlorate reduction comes in part from the Energy Biosciences Institute to John D. Coates. The authors wish to thank Tyler Barnum, Anna Engelbrektson, and Nazar Akhverdyan for their invaluable comments to this manuscript. Ouwei Wang would also like to acknowledge financial support from the ARCS Foundation Fellowship.

Conflicts of Interest: The authors hold several patents on the application of (per)chlorate reduction, genes, and enzymes.

\section{References}

1. Urbansky, E.T. Perchlorate as an environmental contaminant. Environ. Sci. Pollut. Res. 2002, 9, 187-192. [CrossRef]

2. Rajagopalan, S.; Anderson, T.; Cox, S.; Harvey, G.; Cheng, Q.; Jackson, W.A. Perchlorate in wet deposition across north america. Environ. Sci. Technol. 2009, 43, 616-622. [CrossRef] [PubMed]

3. Nilsson, T.; Rova, M.; Smedja Bäcklund, A. Microbial metabolism of oxochlorates: A bioenergetic perspective. Biochim. Biophys. Acta 2013, 1827, 189-197. [CrossRef] [PubMed]

4. Motzer, W.E. Perchlorate: Problems, detection, and solutions. Environ. Forensics 2001, 2, 301-311. [CrossRef] 
5. Dasgupta, P.K.; Martinelango, P.K.; Jackson, W.A.; Anderson, T.A.; Tian, K.; Tock, R.W.; Rajagopalan, S. The origin of naturally occurring perchlorate: The role of atmospheric processes. Environ. Sci. Technol. 2005, 39, 1569-1575. [CrossRef] [PubMed]

6. Catling, D.; Claire, M.; Zahnle, K.; Quinn, R.; Clark, B.; Hecht, M.; Kounaves, S. Atmospheric origins of perchlorate on mars and in the atacama. J. Geophys. Res. Planets (1991-2012) 2010, 115. [CrossRef]

7. Mastrocicco, M.; Di Giuseppe, D.; Vincenzi, F.; Colombani, N.; Castaldelli, G. Chlorate origin and fate in shallow groundwater below agricultural landscapes. Environ. Pollut. 2017, 231, 1453-1462. [CrossRef] [PubMed]

8. Kounaves, S.P.; Stroble, S.T.; Anderson, R.M.; Moore, Q.; Catling, D.C.; Douglas, S.; McKay, C.P.; Ming, D.W.; Smith, P.H.; Tamppari, L.K.; et al. Discovery of natural perchlorate in the antarctic dry valleys and its global implications. Environ. Sci. Technol. 2010, 44, 2360-2364. [CrossRef] [PubMed]

9. Urbansky, E.T. Perchlorate chemistry: Implications for analysis and remediation. Bioremediat. J. 1998, 2, 81-95. [CrossRef]

10. Urbanski, T. Chemistry and Technology of Explosives; Pergamon Press: New York, NY, USA, 1988; Volume 4, pp. 602-620.

11. Roote, D. Technology Status Report-Perchlorate Treatment Technologies; Ground-Water Remediation Technologies Analysis Center: Pittsburgh, PA, USA, 15 May 2001.

12. Stanbury, J.B.; Wyngaarden, J.B. Effect of perchlorate on the human thyroid gland. Metab. Clin. Exp. 1952, 1, 533-539. [PubMed]

13. Wolff, J. Perchlorate and the thyroid gland. Pharmacol. Rev. 1998, 50, 89-106. [PubMed]

14. Clark, J.J.J. Toxicology of perchlorate. In Perchlorate in the Environment; Urbansky, E.T., Ed.; Springer: Boston, MA, USA, 2000; pp. 15-29.

15. Abt, E.; Spungen, J.; Pouillot, R.; Gamalo-Siebers, M.; Wirtz, M. Update on dietary intake of perchlorate and iodine from U.S. Food and drug administration's total diet study: 2008-2012. J. Expo. Sci. Environ. Epidemiol. 2016. [CrossRef] [PubMed]

16. Engelbrektson, A.; Hubbard, C.G.; Tom, L.M.; Boussina, A.; Jin, Y.T.; Wong, H.; Piceno, Y.M.; Carlson, H.K.; Conrad, M.E.; Anderson, G. Inhibition of microbial sulfate reduction in a flow-through column system by (per)chlorate treatment. Front. Microbiol. 2014, 5, 315. [CrossRef] [PubMed]

17. Deshwal, B.; Lee, H.-K. Kinetics and mechanism of chloride based chlorine dioxide generation process from acidic sodium chlorate. J. Hazard. Mater. 2004, 108, 173-182. [CrossRef] [PubMed]

18. Coates, J.D.; Achenbach, L.A. Microbial perchlorate reduction: Rocket-fuelled metabolism. Nat. Rev. Microbiol. 2004, 2, 569-580. [CrossRef] [PubMed]

19. Youngblut, M.D.; Wang, O.; Barnum, T.P.; Coates, J.D. (Per)chlorate in biology on earth and beyond. Annu. Rev. Microbiol. 2016, 70, 435-457. [CrossRef] [PubMed]

20. Condie, L.W. Toxicological problems associated with chlorine dioxide. J. (Am. Water Works Assoc.) 1986, 78, 73-78.

21. Daniel, F.B.; Condie, L.W.; Robinson, M.; Stober, J.A.; York, R.G.; Olson, G.R.; Wang, S.-R. Comparative subchronic toxicity studies of three disinfectants (pdf). J. (Am. Water Works Assoc.) 1990, 82, 61-69.

22. Vanwijk, D.J.; Hutchinson, T.H. The ecotoxicity of chlorate to aquatic organisms: A critical review. Ecotoxicol. Environ. Saf. 1995, 32, 244-253. [CrossRef]

23. Ingram, P.R.; Pitt, A.R.; Wilson, C.G.; Olejnik, O.; Spickett, C.M. A comparison of the effects of ocular preservatives on mammalian and microbial atp and glutathione levels. Free Radic. Res. 2004, 38, 739-750. [CrossRef] [PubMed]

24. Ingram, P.R.; Homer, N.Z.; Smith, R.A.; Pitt, A.R.; Wilson, C.G.; Olejnik, O.; Spickett, C.M. The interaction of sodium chlorite with phospholipids and glutathione: A comparison of effects in vitro, in mammalian and in microbial cells. Arch. Biochem. Biophys. 2003, 410, 121-133. [CrossRef]

25. Van Wijk, D.J.; Kroon, S.G.; Garttener-Arends, I.C. Toxicity of chlorate and chlorite to selected species of algae, bacteria, and fungi. Ecotoxicol. Environ. Saf. 1998, 40, 206-211. [CrossRef] [PubMed]

26. Gagnon, G.; Rand, J.; O'leary, K.; Rygel, A.; Chauret, C.; Andrews, R. Disinfectant efficacy of chlorite and chlorine dioxide in drinking water biofilms. Water Res. 2005, 39, 1809-1817. [CrossRef] [PubMed]

27. Allende, A.; McEvoy, J.; Tao, Y.; Luo, Y. Antimicrobial effect of acidified sodium chlorite, sodium chlorite, sodium hypochlorite, and citric acid on Escherichia coli O157:H7 and natural microflora of fresh-cut cilantro. Food Control 2009, 20, 230-234. [CrossRef] 
28. Luo, Y.; Lu, S.; Zhou, B.; Feng, H. Dual effectiveness of sodium chlorite for enzymatic browning inhibition and microbial inactivation on fresh-cut apples. LWT Food Sci. Technol. 2011, 44, 1621-1625. [CrossRef]

29. Bichai, F.; Barbeau, B. Assessing the disinfecting power of chlorite in drinking water. Water Qual. Res. J. Can. 2006, 41, 375-382.

30. Dempster, R.P.; Morales, P.; Glennon, F.X. Use of sodium chlorite to combat anchorworm infestations of fish. Progress. Fish-Cult. 1988, 50, 51-55. [CrossRef]

31. Åslander, A. Experiments on the Eradication of Canada Thistle: Cirsium Arvense, with Chlorates and Other Herbicides; US Government Printing Office: Washington, DC, USA, 1928.

32. Youngblut, M.D.; Tsai, C.-L.; Clark, I.C.; Carlson, H.K.; Maglaqui, A.P.; Gau-pan, P.S.; Redford, S.A.; Wong, A.; Tainer, J.A.; Coates, J.D. Perchlorate reductase is distinguished by active site aromatic gate residues. J. Biol. Chem. 2016, 291, 9190-9202. [CrossRef] [PubMed]

33. Clark, I.C.; Melnyk, R.A.; Engelbrektson, A.; Coates, J.D. Structure and evolution of chlorate reduction composite transposons. mBio 2013, 4. [CrossRef] [PubMed]

34. Clark, I.C.; Melnyk, R.A.; Iavarone, A.T.; Novichkov, P.S.; Coates, J.D. Chlorate reduction in shewanella algae acdc is a recently acquired metabolism characterized by gene loss, suboptimal regulation and oxidative stress. Mol. Microbiol. 2014, 94, 107-125. [CrossRef] [PubMed]

35. Clark, I.C.; Melnyk, R.A.; Youngblut, M.D.; Carlson, H.K.; Iavarone, A.T.; Coates, J.D. Synthetic and evolutionary construction of a chlorate-reducing shewanella oneidensis MR-1. mBio 2015, 6. [CrossRef] [PubMed]

36. Clark, I.C.; Youngblut, M.; Jacobsen, G.; Wetmore, K.M.; Deutschbauer, A.; Lucas, L.; Coates, J.D. Genetic dissection of chlorate respiration in pseudomonas stutzeri pda reveals syntrophic (per)chlorate reduction. Environ. Microbiol. 2016, 18, 3342-3354. [CrossRef] [PubMed]

37. Thorell, H.D.; Stenklo, K.; Karlsson, J.; Nilsson, T. A gene cluster for chlorate metabolism in ideonella dechloratans. Appl. Environ. Microbiol. 2003, 69, 5585-5592. [CrossRef] [PubMed]

38. Coates, J.; Jackson, A. Principles of perchlorate treatment. In In Situ Bioremediation of Perchlorate in Groundwater; Springer: Norwell, MA, USA, 2008.

39. Stepanov, V.G.; Xiao, Y.; Tran, Q.; Rojas, M.; Willson, R.C.; Fofanov, Y.; Fox, G.E.; Roberts, D.J. The presence of nitrate dramatically changed the predominant microbial community in perchlorate degrading cultures under saline conditions. BMC Microbiol. 2014, 14, 225. [CrossRef] [PubMed]

40. Srinivasan, A.; Viraraghavan, T. Perchlorate: Health effects and technologies for its removal from water resources. Int. J. Environ. Res. Public Health 2009, 6, 1418-1442. [CrossRef] [PubMed]

41. Carlstrom, C.I.; Loutey, D.E.; Wang, O.; Engelbrektson, A.; Clark, I.; Lucas, L.N.; Somasekhar, P.Y.; Coates, J.D. Phenotypic and genotypic description of sedimenticola selenatireducens strain CUZ, a marine (per)chlorate-respiring gammaproteobacterium, and its close relative the chlorate-respiring sedimenticola strain NSS. Appl. Environ. Microbiol. 2015, 81, 2717-2726. [CrossRef] [PubMed]

42. Carlström, C.I.; Wang, O.; Melnyk, R.A.; Bauer, S.; Lee, J.; Engelbrektson, A.; Coates, J.D. Physiological and genetic description of dissimilatory perchlorate reduction by the novel marine bacterium Arcobacter sp. Strain CAB. mBio 2013, 4. [CrossRef] [PubMed]

43. Okeke, B.C.; Giblin, T.; Frankenberger, W.T., Jr. Reduction of perchlorate and nitrate by salt tolerant bacteria. Environ. Pollut. 2002, 118, 357-363. [CrossRef]

44. Xiao, Y.; Roberts, D.J. Kinetics analysis of a salt-tolerant perchlorate-reducing bacterium: Effects of sodium, magnesium, and nitrate. Environ. Sci. Technol. 2013, 47, 8666-8673. [CrossRef] [PubMed]

45. Ahn, C.H.; Oh, H.; Ki, D.; Van Ginkel, S.W.; Rittmann, B.E.; Park, J. Bacterial biofilm-community selection during autohydrogenotrophic reduction of nitrate and perchlorate in ion-exchange brine. Appl. Microbiol. Biotechnol. 2009, 81, 1169-1177. [CrossRef] [PubMed]

46. Chung, J.; Shin, S.; Oh, J. Characterization of a microbial community capable of reducing perchlorate and nitrate in high salinity. Biotechnol. Lett. 2009, 31, 959-966. [CrossRef] [PubMed]

47. Zuo, G.; Roberts, D.; Lehman, S.; Jackson, G.; Fox, G.; Willson, R. Molecular assessment of salt-tolerant, perchlorate-and nitrate-reducing microbial cultures. Water Sci. Technol. 2009, 60, 1745-1756. [CrossRef] [PubMed]

48. Giblin, T.L.; Herman, D.C.; Frankenberger, W. Removal of perchlorate from ground water by hydrogen-utilizing bacteria. J. Environ. Qual. 2000, 29, 1057-1062. [CrossRef] 
49. Logan, B.E.; LaPoint, D. Treatment of perchlorate-and nitrate-contaminated groundwater in an autotrophic, gas phase, packed-bed bioreactor. Water Res. 2002, 36, 3647-3653. [CrossRef]

50. Miller, J.P.; Logan, B.E. Sustained perchlorate degradation in an autotrophic, gas-phase, packed-bed bioreactor. Environ. Sci. Technol. 2000, 34, 3018-3022. [CrossRef]

51. Nerenberg, R.; Rittmann, B. Hydrogen-based, hollow-fiber membrane biofilm reactor for reduction of perchlorate and other oxidized contaminants. Water Sci. Technol. 2004, 49, 223-230. [PubMed]

52. Son, A.; Lee, J.; Chiu, P.C.; Kim, B.J.; Cha, D.K. Microbial reduction of perchlorate with zero-valent iron. Water Res. 2006, 40, 2027-2032. [CrossRef] [PubMed]

53. Sahu, A.K.; Conneely, T.; Nüsslein, K.R.; Ergas, S.J. Biological perchlorate reduction in packed bed reactors using elemental sulfur. Environ. Sci. Technol. 2009, 43, 4466-4471. [CrossRef] [PubMed]

54. Xu, J.; Song, Y.; Min, B.; Steinberg, L.; Logan, B.E. Microbial degradation of perchlorate: Principles and applications. Environ. Eng. Sci. 2003, 20, 405-422. [CrossRef]

55. Hatzinger, P.B. Perchlorate biodegradation for water treatment. Environ. Sci. Technol. 2005, 39, 239A-247A. [CrossRef] [PubMed]

56. Thrash, J.C.; Van Trump, J.I.; Weber, K.A.; Miller, E.; Achenbach, L.A.; Coates, J.D. Electrochemical stimulation of microbial perchlorate reduction. Environ. Sci. Technol. 2007, 41, 1740-1746. [CrossRef] [PubMed]

57. Brown, J.C.; Anderson, R.D.; Min, J.H.; Boulos, L.; Prasifka, D.; Juby, G.J. Fixed-bed biological treatment of perchlorate-contaminated drinking water. J. (Am. Water Works Assoc.) 2005, 97, 70-81.

58. Thrash, J.C.; Coates, J.D. Review: Direct and indirect electrical stimulation of microbial metabolism. Environ. Sci. Technol. 2008, 42, 3921-3931. [CrossRef] [PubMed]

59. Rook, J.J. Haloforms in drinking water. J. (Am. Water Works Assoc.) 1976, 68, 168-172.

60. Coates, J.D.; Thrash, C.J. Bioelectrical Treatment of Xenobiotics. WO2,008,140,590 A2, 20 November 2008.

61. Shea, C.; Clauwaert, P.; Verstraete, W.; Nerenberg, R. Adapting a denitrifying biocathode for perchlorate reduction. Water Sci. Technol. 2008, 58, 1941-1946. [CrossRef] [PubMed]

62. Clark, I.C.; Carlson, H.K.; Iavarone, A.T.; Coates, J.D. Bioelectrical redox cycling of anthraquinone-2, 6-disulfonate coupled to perchlorate reduction. Energy Environ. Sci. 2012, 5, 7970-7978. [CrossRef]

63. Lovley, D.R. Electromicrobiology. Ann. Rev. Microbiol. 2012, 66, 391-409. [CrossRef] [PubMed]

64. Dang, Y.; Holmes, D.E.; Zhao, Z.; Woodard, T.L.; Zhang, Y.; Sun, D.; Wang, L.; Nevin, K.P.; Lovley, D.R. Enhancing anaerobic digestion of complex organic waste with carbon-based conductive materials. Bioresour. Technol. 2016, 220, 516-522. [CrossRef] [PubMed]

65. El Aribi, H.; Le Blanc, Y.J.; Antonsen, S.; Sakuma, T. Analysis of perchlorate in foods and beverages by ion chromatography coupled with tandem mass spectrometry (IC-ESI-MS/MS). Anal. Chim. Acta 2006, 567, 39-47. [CrossRef] [PubMed]

66. Jackson, P.; Gokhale, S.; Streib, T.; Rohrer, J.; Pohl, C. Improved method for the determination of trace perchlorate in ground and drinking waters by ion chromatography. J. Chromatogr. A 2000, 888, 151-158. [CrossRef]

67. Valentín-Blasini, L.; Blount, B.C.; Delinsky, A. Quantification of iodide and sodium-iodide symporter inhibitors in human urine using ion chromatography tandem mass spectrometry. J. Chromatogr. A 2007, 1155, 40-46. [CrossRef] [PubMed]

68. Heinnickel, M.; Smith, S.C.; Koo, J.; O'Connor, S.M.; Coates, J.D. A bioassay for the detection of perchlorate in the ppb range. Environ. Sci. Technol. 2011, 45, 2958-2964. [CrossRef] [PubMed]

69. Coates, J.D.; Heinnickel, M.; Achenbach, L.A. An Enzymatic Bioassay for Perchlorate. Available online: https:/ / clu-in.org/download/contaminantfocus / perchlorate/Perchlorate-ER-1530-FR.pdf (accessed on 23 November 2017).

70. Glavin, D.P.; Freissinet, C.; Miller, K.E.; Eigenbrode, J.L.; Brunner, A.E.; Buch, A.; Sutter, B.; Archer, P.D., Jr.; Atreya, S.K.; Brinckerhoff, W.B.; et al. Evidence for perchlorates and the origin of chlorinated hydrocarbons detected by sam at the rocknest aeolian deposit in gale crater. J. Geophys. Res. Planets 2013, 118, 1955-1973. [CrossRef]

71. Navarro-González, R.; Vargas, E.; de la Rosa, J.; Raga, A.C.; McKay, C.P. Reanalysis of the viking results suggests perchlorate and organics at midlatitudes on Mars. J. Geophys. Res. 2010, 115, E12010. [CrossRef]

72. Jackson, W.A.; Davila, A.F.; Sears, D.W.G.; Coates, J.D.; McKay, C.P.; Brundrett, M.; Estrada, N.; Böhlke, J.K. Widespread occurrence of (per)chlorate in the solar system. Earth Planet. Sci. Lett. 2015, 430, 470-476. [CrossRef] 
73. Davila, A.F.; Willson, D.; Coates, J.D.; McKay, C.P. Perchlorate on mars: A chemical hazard and a resource for humans. Int. J. Astrobiol. 2013, 12, 321-325. [CrossRef]

74. Urbansky, E.T.; Brown, S.K. Perchlorate retention and mobility in soils. J. Environ. Monit. 2003, 5, 455-462. [CrossRef] [PubMed]

75. Gregoire, P.; Engelbrektson, A.; Hubbard, C.G.; Metlagel, Z.; Csencsits, R.; Auer, M.; Conrad, M.E.; Thieme, J.; Northrup, P.; Coates, J.D. Control of sulfidogenesis through bio-oxidation of $\mathrm{H}_{2} \mathrm{~S}$ coupled to (per)chlorate reduction. Environ. Microbiol. Rep. 2014, 6, 558-564. [CrossRef] [PubMed]

76. Gieg, L.M.; Jack, T.R.; Foght, J.M. Biological souring and mitigation in oil reservoirs. Appl. Microbiol. Biotechnol. 2011, 92, 263-282. [CrossRef] [PubMed]

77. Youssef, N.; Elshahed, M.S.; McInerney, M.J. Microbial processes in oil fields: Culprits, problems, and opportunities. Adv. Appl. Microbiol. 2009, 66, 141-251. [PubMed]

78. Carlson, H.K.; Kuehl, J.V.; Hazra, A.B.; Justice, N.B.; Stoeva, M.K.; Sczesnak, A.; Mullan, M.R.; Iavarone, A.T.; Engelbrektson, A.; Price, M.N. Mechanisms of direct inhibition of the respiratory sulfate-reduction pathway by (per)chlorate and nitrate. ISME J. 2015, 9, 1295-1305. [CrossRef] [PubMed]

79. Voordouw, G.; Grigoryan, A.A.; Lambo, A.; Lin, S.; Park, H.S.; Jack, T.R.; Coombe, D.; Clay, B.; Zhang, F.; Ertmoed, R. Sulfide remediation by pulsed injection of nitrate into a low temperature canadian heavy oil reservoir. Environ. Sci. Technol. 2009, 43, 9512-9518. [CrossRef] [PubMed]

80. Hubert, C. Microbial ecology of oil reservoir souring and its control by nitrate injection. In Handbook of Hydrocarbon and Lipid Microbiology; Springer: Berlin/Heidelberg, Germany, 2010; pp. 2753-2766.

81. Lovley, D.R.; Goodwin, S. Hydrogen concentrations as an indicator of the predominant terminal electron accepting reactions in aquatic sediments. Geochim. Cosmochim. Acta 1988, 52, 2993-3003. [CrossRef]

82. Callbeck, C.M.; Agrawal, A.; Voordouw, G. Acetate production from oil under sulfate-reducing conditions in bioreactors injected with sulfate and nitrate. Appl. Environ. Microbiol. 2013, 79, 5059-5068. [CrossRef] [PubMed]

83. Moura, I.; Bursakov, S.; Costa, C.; Moura, J.J. Nitrate and nitrite utilization in sulfate-reducing bacteria. Anaerobe 1997, 3, 279-290. [CrossRef] [PubMed]

84. Mehta-Kolte, M.G.; Loutey, D.; Wang, O.; Youngblut, M.D.; Hubbard, C.G.; Wetmore, K.M.; Conrad, M.E.; Coates, J.D. Mechanism of $\mathrm{H}_{2} \mathrm{~S}$ oxidation by the dissimilatory perchlorate-reducing microorganism Azospira suillum PS. mBio 2017, 8. [CrossRef] [PubMed]

85. Shrestha, P.; Williamson, A.D.; Liu, Y.; Nowak, J.; Loutey, D.; Louie, W.; Kim, H.; Goldstein, A.; Ajo-Franklin, J.; Coates, J.D. University of California: Berkeley, CA, USA, Unpublished work. 2017.

86. Díaz, E.; Jiménez, J.I.; Nogales, J. Aerobic degradation of aromatic compounds. Curr. Opin. Biotechnol. 2013, 24, 431-442. [CrossRef] [PubMed]

87. Carmona, M.; Zamarro, M.T.; Blázquez, B.; Durante-Rodríguez, G.; Juárez, J.F.; Valderrama, J.A.; Barragán, M.J.; García, J.L.; Díaz, E. Anaerobic catabolism of aromatic compounds: A genetic and genomic view. Microbiol. Mol. Biol. Rev. 2009, 73, 71-133. [CrossRef] [PubMed]

88. Samanta, S.K.; Singh, O.V.; Jain, R.K. Polycyclic aromatic hydrocarbons: Environmental pollution and bioremediation. Trends Biotechnol. 2002, 20, 243-248. [CrossRef]

89. Jiménez, J.I.; Miñambres, B.; García, J.L.; Díaz, E. Genomic analysis of the aromatic catabolic pathways from Pseudomonas putida KT2440. Environ. Microbiol. 2002, 4, 824-841. [CrossRef] [PubMed]

90. Basu, A.; Apte, S.K.; Phale, P.S. Preferential utilization of aromatic compounds over glucose by pseudomonas putida CSV86. Appl. Environ. Microbiol. 2006, 72, 2226-2230. [CrossRef] [PubMed]

91. Lovley, D. Potential for anaerobic bioremediation of btex in petroleum-contaminated aquifers. J. Ind. Microbiol. Biotechnol. 1997, 18, 75-81. [CrossRef]

92. Fuchs, G.; Boll, M.; Heider, J. Microbial degradation of aromatic compounds-From one strategy to four. Nat. Rev. Microbiol. 2011, 9, 803-816. [CrossRef] [PubMed]

93. Ismail, W.; Gescher, J. Epoxy coenzyme a thioester pathways for degradation of aromatic compounds. Appl. Environ. Microbiol. 2012, 78, 5043-5051. [CrossRef] [PubMed]

94. Coates, J.D.; Chakraborty, R.; Lack, J.G.; O'connor, S.M.; Cole, K.A.; Bender, K.S.; Achenbach, L.A. Anaerobic benzene oxidation coupled to nitrate reduction in pure culture by two strains of dechloromonas. Nature 2001, 411, 1039-1043. [CrossRef] [PubMed]

95. Coates, J.D.; Bruce, R.A.; Patrick, J.A.; Achenbach, L.A. Hydrocarbon bioremediative potential of (per)chlorate-reducing bacteria. Bioremediat. J. 1999, 3, 323-334. [CrossRef] 
96. Coates, J.D.; Bruce, R.A.; Haddock, J.D. Anoxic bioremediation of hydrocarbons. Nature 1998, $396,730$. [CrossRef] [PubMed]

97. Brundrett, M.; Horita, J.; Anderson, T.; Pardue, J.; Reible, D.; Jackson, W.A. The use of chlorate, nitrate, and perchlorate to promote crude oil mineralization in salt marsh sediments. Environ. Sci. Pollut. Res. 2015, 22, 15377-15385. [CrossRef] [PubMed]

98. Miller, L.G.; Baesman, S.M.; Carlstrom, C.I.; Coates, J.D.; Oremland, R.S. Methane oxidation linked to chlorite dismutation. Front. Microbiol. 2014, 5, 275. [CrossRef] [PubMed]

99. Melnyk, R.A.; Clark, I.C.; Liao, A.; Coates, J.D. Transposon and deletion mutagenesis of genes involved in perchlorate reduction in azospira suillum PS. mBio 2014, 5. [CrossRef] [PubMed]

100. Melnyk, R.A.; Youngblut, M.D.; Clark, I.C.; Carlson, H.K.; Wetmore, K.M.; Price, M.N.; Iavarone, A.T.; Deutschbauer, A.M.; Arkin, A.P.; Coates, J.D. Novel mechanism for scavenging of hypochlorite involving a periplasmic methionine-rich peptide and methionine sulfoxide reductase. mBio 2015, 6. [CrossRef] [PubMed]

101. Verreault, D.; Gendron, L.; Rousseau, G.M.; Veillette, M.; Massé, D.; Lindsley, W.G.; Moineau, S.; Duchaine, C. Detection of airborne lactococcal bacteriophages in cheese manufacturing plants. Appl. Environ. Microbiol. 2011, 77, 491-497. [CrossRef] [PubMed]

102. Jones, D.T.; Shirley, M.; Wu, X.; Keis, S. Bacteriophage infections in the industrial acetone butanol (ab) fermentation process. J. Mol. Microbiol. Biotechnol. 2000, 2, 21-26. [PubMed]

103. Marcó, M.B.; Moineau, S.; Quiberoni, A. Bacteriophages and dairy fermentations. Bacteriophage 2012, 2, 149-158. [CrossRef] [PubMed]

104. Callanan, M.J.; Klaenhammer, T.R. Bacteriophages in industry. eLS 2008. [CrossRef]

105. Martín, M.; Montes, F.J.; Galán, M.A. Bubbling process in stirred tank reactors II: Agitator effect on the mass transfer rates. Chem. Eng. Sci. 2008, 63, 3223-3234. [CrossRef]

106. Karimi, A.; Golbabaei, F.; Mehrnia, M.R.; Neghab, M.; Mohammad, K.; Nikpey, A.; Pourmand, M.R. Oxygen mass transfer in a stirred tank bioreactor using different impeller configurations for environmental purposes. Iran. J. Environ. Health Sci. Eng. 2013, 10, 6. [CrossRef] [PubMed]

107. Garcia-Ochoa, F.; Gomez, E. Bioreactor scale-up and oxygen transfer rate in microbial processes: An overview. Biotechnol. Adv. 2009, 27, 153-176. [CrossRef] [PubMed]

108. Krebs, C.; Dassama, L.M.; Matthews, M.L.; Jiang, W.; Price, J.C.; Korboukh, V.; Li, N.; Bollinger, J.M. Novel approaches for the accumulation of oxygenated intermediates to multi-millimolar concentrations. Coord. Chem. Rev. 2013, 257, 234-243. [CrossRef] [PubMed]

109. Dassama, L.M.; Yosca, T.H.; Conner, D.A.; Lee, M.H.; Blanc, B.; Streit, B.R.; Green, M.T.; DuBois, J.L.; Krebs, C.; Bollinger, J.M., Jr. $\mathrm{O}_{2}$-evolving chlorite dismutase as a tool for studying $\mathrm{O}_{2}$-utilizing enzymes. Biochemistry 2012, 51, 1607-1616. [CrossRef] [PubMed]

110. Mölder, E.; Mashirin, A.; Tenno, T. Measurement of the oxygen mass transfer through the air-water interface (5 pp). Environ. Sci. Pollut. Res. 2005, 12, 66-70. [CrossRef]

111. Rui, Z.; Li, X.; Zhu, X.; Liu, J.; Domigan, B.; Barr, I.; Cate, J.H.; Zhang, W. Microbial biosynthesis of medium-chain 1-alkenes by a nonheme iron oxidase. Proc. Natl. Acad. Sci. USA 2014, 111, 18237-18242. [CrossRef] [PubMed]

112. Wang, C.; Chang, W.-C.; Guo, Y.; Huang, H.; Peck, S.C.; Pandelia, M.E.; Lin, G.-M.; Liu, H.-W.; Krebs, C.; Bollinger, J.M. Evidence that the fosfomycin-producing epoxidase, HppE, is a non-heme-iron peroxidase. Science 2013, 342, 991-995. [CrossRef] [PubMed]

113. Coates, J.D.; Michaelidou, U.; Bruce, R.A.; O'Connor, S.M.; Crespi, J.N.; Achenbach, L.A. The ubiquity and diversity of dissimilatory (per)chlorate-reducing bacteria. Appl. Environ. Microbiol. 1999, 65, 5234-5241. [PubMed]

(C) 2017 by the authors. Licensee MDPI, Basel, Switzerland. This article is an open access article distributed under the terms and conditions of the Creative Commons Attribution (CC BY) license (http:/ / creativecommons.org/licenses/by/4.0/). 